\title{
The Radical Left after 1968: From Ideological Craze to Reconfiguration of Politics
}

\author{
Luca Falciola \\ New York University
}

Eleanor Davey, Idealism beyond Borders: The French Revolutionary Left and the Rise of Humanitarianism, 1954-1988. Cambridge and New York: Cambridge University Press, 2015. 346 pp. \$99.99.

Howard Brick and Christopher Phelps, Radicals in America: The U.S. Left since the Second World War. Cambridge and New York: Cambridge University Press, 2015. 355 pp. \$24.99.

Takemasa Ando, Japan's New Left Movements: Legacies for Civil Society. Abingdon, Oxon, and New York: Routledge, 2014. 208 pp. $\$ 53.95$

Guobin Yang, The Red Guard Generation and Political Activism in China. New York: Columbia University Press, 2016. 262 pp. \$26.00.

By the mid-1970s, Jerry Rubin - icon of American radicalism and cofounder of the Yippies, who campaigned in 1968 to elect a pig as president of the United States and appeared before the House Un-American Activities Committee dressed in an eighteenth-century Revolutionary War uniform-had transformed himself from protester to successful businessman. He launched a new career on Wall Street as a stockbroker, became known for his promotion of "networking," bringing together yuppies at parties in Manhattan, and was an early investor in Apple Computer. For a long time, both in public memory and in many historical accounts, Rubin's conversion embodied the path of an entire generation of leftists who hastily shifted from the ideological craze of 1968-1970 to the disillusionment of the so-called "me decade."

Undeniably, after a broad and intense radicalization, the bulk of militants in the United States and elsewhere in the world rapidly disengaged. Some of the onetime overheated activists ceased to be worried about the Vietnam War, some others were simply disaffected by a promethean revolution that appeared out of reach, and yet others were burned out by their failed attempts to trigger armed 
struggle. However, recent international scholarship on the radical left has done much to correct this interpretation by showing that the 1970s and the 1980s did not represent decades of absolute de-politicization and pure hedonism. In fact, the transition from the so-called "days of rage" to the subsequent apathy did not necessarily take the form of a widespread and inevitable backlash.

The four books under review analyze different aspects of leftist history, adopt diverging perspectives, and survey disparate-some historians would say incomparable-contexts. Yet, they invariably turn their attention to the transformation of the full-fledged idealism of the late 1960s into something different, but not necessarily antithetical. In particular, the four volumes explain more in detail how such a reconversion took place, revising its extent and reassessing its outcomes. In doing so, they bring to light factors that underlie the process of deradicalization, revealing not only its complexity, but also some recurring patterns. As a result, they offer a rare glimpse into the history of that controversial period and provide valuable insights for the social scientists who are, today more than ever, interested in the logic of political extremism. ${ }^{1}$

Eleanor Davey's Idealism beyond Borders: The French Revolutionary Left and the Rise of Humanitarianism, 1954-1988 compellingly addresses this issue by focusing on the evolution of a particular stream of leftist activism, that is French third-worldism. The book is a dense, well-sourced, and erudite piece of historiography. The fascination with Third World revolution, explains Davey, manifested itself in theoretical, literary, and cultural forms and crossed multiple generations of leftist militants after the experience of the Algerian War. Third-worldism gained its largest audience in the wake of May 1968, when the Vietcong, the Cuban insurgents, the Maoist Red Guards, the Tupamaros guerrillas, and the Palestinian Fedayeen - to mention just the most popular references-cohabited a multifaceted Pantheon of revolutionary heroes. This brought together, within the radical left, not only an invaluable source of inspiration and a focus on international solidarity, but also a rationalization and, sometimes, a celebration of political violence.

However, such revolutionary enthusiasm faltered as it became more difficult to ignore the abuses of some postcolonial Third World rulers, who increasingly showed signs of despotism and repression. Concurrent with the third-worldist phase of disillusionment, the radical humanitarianism of the "sans-frontiériste movement," pioneered by the organization Médecins Sans Frontières (MSF), emerged as an alternative model of engagement for many leftists. Intellectuals and militants who repudiated, or simply criticized, their own ideological references made human rights the cornerstone of their future campaigns.

To explain this reconversion, Davey's work accurately retraces the complex interplay of factors that eroded the myth of the Third World freedom fighters, jeopardized Soviet moral authority, and weakened Marxist interpretive paradigms. The book also explains how universalism, idealism, interest in the Third World, solidarity with the suffering of others, and moral imperative for action - values that outlasted the ideological crisis-were channeled into this 
new stand. Overall, this reassessment helped avoid both the downward spiral of political violence and the retreat into private.

First of all, the author focuses on a few international events and the ensuing cultural debates that developed in France. For example, she explains how the arrest of Cuban leftist poet Heberto Padilla by Castroist authorities, followed by his incredible self-criticism and public humiliation in Spring 1971, marked the symbolic end of the French love affair with the Cuban revolutionaries. The foreign intellectuals who had previously supported the guerrilleros publicly aired their disenchantment and immediately lost their privileged ties to the country. Soon, Mao and his Great Proletarian Cultural Revolution followed Cuba's fate. As information about abuses in China grew and the excesses of Mao's Red Guards became more apparent, French Maoists and the large pro-Chinese cohort abandoned their favorites. The publication in 1975 in France of journalist Jean Pasqualini's account of his seven years in a Chinese labor camp dealt a major blow. Even Jean-Paul Sartre, who actively backed Maoist initiatives, and Alain Geismar, leader of the Gauche prolétarienne (GP), the most contentious Maoist group of the country, acknowledged Pasqualini's role in revealing the coercive nature of the Chinese regime.

Also crucial to these changes in the intellectual and ideological paradigms was the French-language publishing, in June 1974, of the first volume of Solzhenitsyn's The Gulag Archipelago, which became an extraordinary literary case. "The 'discovery' of the Soviet Gulag" - Davey rightly notes - "made dissidence a watchword of French extra-parliamentary politics in the 1970s" (113). Campaigns in support of political prisoners raised increasing attention, with a focus on the exiles, the convicts, and the refugees fighting for their freedom, even from the revolutions in power. As a result, "the sacred distinction" between left-wing and right-wing powers was challenged by a vision that emphasized the presence of camps on both sides of the ideological divide. Such desanctification of Manichean constructions and the ensuing refusal to choose "good and bad deaths," as Davey points out, also resonated in the nouveaux philosophes' message, whose unifying motif was antitotalitarianism.

Quite paradoxically, observes Davey, French Maoist militants used the practice of self-criticism to undermine the reputation of revolutionary China. A cornerstone of Mao's catechism, self-criticism was originally intended to protect revolutionary purity by repeatedly signaling, discussing, and rectifying errors. Nonetheless, it became a tool to call ideological dogmas into question and eventually dismantle them. As a matter of fact, the habit of self-criticism found powerful expression in the memoirs of disillusioned Maoists such as Jacques and Claudie Broyelle or Jean-Pierre Le Dantec. Likewise, MSF founder and former Maoist sympathizer Bernard Kouchner, following the ritual of self-criticism, in 1978 portrayed gauchiste militancy as delusional, free from physical risk, morbid, and incapable of admitting its masculine taste for spectacular violence (134).

Finally, Davey identifies a last factor that contributed to this deep ideological revision: namely, the centrality of the memory of the Second World War. 
The generation of activists who had come to maturity under the sign of 1968 had, in the words of Bernard Kouchner, "grown up in the cult of the French Resistance and the imitation of History" and made constant, incantatory reference to the period of the Occupation, Resistance, and Holocaust (112). To put it simply, they saw themselves as the successors of the antifascist combatants of the Second World War. Confronted in the 1970s with both the genocidal violence of the revolutionary regimes and the terrorist activities of some left-wing fringes, French leftists had to face their own "complicity" in the type of violence they meant to resist. For example, members of the Gauche prolétarienne, who previously supported the Palestinian movement and advocated its use of "revolutionary violence," began to rethink their militant engagement following the Black September assault at the Munich Olympics in 1972. The leaders of the GP found themselves almost unanimous in the rejection of the logic of the Munich attack, which resulted in the death of eleven Israeli athletes, five Fedayeen, and a German police officer. The shock of French Maoists in the face of such an event was among the key factors behind the organization's autodissolution in 1973. The Palestinian attack, according to Davey, had a profound influence on the entire French radical left, where a large number of militants shared Jewish origins, and was eventually "the catalyst for an acute focus on the issues of individual and collective responsibility, in light of the Holocaust legacy" (152).

The memory of the crimes of the Second World War, and in particular the sense of guilt for French cooperation with Nazi forces, was also crucial in drawing support of and participation in the humanitarian campaigns for Cambodia and Vietnam after 1975. Complicity, or inaction, was judged as intolerable. For instance, the ubiquitous - not only in the book, but also in the history of French human rights-Bernard Kouchner used to say that his motivation for taking humanitarian action had its source in the legacy of the Holocaust and, specifically, in his indignation for the International Red Cross' refusal to denounce Nazi camps. Going to Vietnam or Cambodia, to again use his words, was to "discover Auschwitz in Asia." On a similar note, renowned leftist journalist Jean Lacouture, in a 1978 essay pleading for action against the Communist Party of Kampuchea (Cambodia), drew striking parallels between the Pol Pot regime and the Third Reich, while openly criticizing Western supporters of Third World revolutionary ideologies.

To be sure, Davey's research navigates on rather mapped territory. On the one hand, Samuel Moyn's pioneering contribution highlighted how, over the course of the 1970s, human rights came to define people's hope for the future, as they were "widely understood as a moral alternative to bankrupt political utopias." 2 On the other hand, the French antitotalitarian debate of the 1970s and the leftists' turn "from revolution to ethics" have been already examined, especially by Julian Bourg's groundbreaking work. ${ }^{3}$ On a critical note, one could also point out that Davey's volume explicitly adopts a narrow perspective, centering on intellectual élites, and inevitably disregards rank-and-file militants. 
Additionally, the book sometimes loses its way in a jungle of debates that the author describes perhaps too minutely.

However, Idealism beyond Borders well succeeds in offering a fresh perspective to the extant literature by drawing attention to at least two crucial aspects. First, it assesses the centrality of Médecins Sans Frontières in the reconfiguration of third-worldism. Davey skillfully analyzes the rise of MSF and connects the history of humanitarianism with that of the radical left and, more broadly, with French cultural history. Second, and most importantly, Davey's work demonstrates that humanitarianism did not represent a mere "backlash against the misplaced utopianism of revolutionary politics" (48) or a leftist ruse to whitewash the militant past. Rather, it was a reevaluation of political paradigms and a new model for engagement. In other words, sans-frontiéristes, while repudiating utopian extremism, somehow kept their radicalism intact, together with their moral commitment. They "served the people," but with medical bags, petitions, and foreign missions, making the post-1968 years an era of continuous activism.

An even greater perception of continuity in the history of leftist radicalism emerges from Radicals in America: The U.S. Left since the Second World War by Howard Brick and Christopher Phelps. The volume is an ambitious, yet successful, systematization of the whole history of American radicalism from 1945 to the present, as well as a fruitful attempt to distill its gist. Radicals in America is the kind of herculean job that only two consummate experts in the field, such as historians Brick and Phelps, could have achieved. A central argument of this extended survey is that the radical left has always represented "a minority current" in an American society that is reluctant to entertain possibilities of dramatic change. Nevertheless, it has propelled major changes and frequently given shape to what Americans broadly take as the nation's core traditions. As a result, margin and mainstream can be seen "as the constitutive duality of the American radical experience" (7). In other words, as the authors gloss, "[d]espite being small in numbers, castigated, and belittled, left-wing radicals have often spurred important movements, won wide hearing for their ideas, and affected policy" (16).

The book has a chronological design, but each chapter tickles readers' interest with a biography that illustrates key themes of the radicalism of that period. The volume opens with the history of radical pacifists - by no means "passivists" - of the 1940s and then moves to the 1950 s by showing how the Red Scare and the near collapse of the Communist Party did not end radical dissent, but rather cleared the way for a new radicalism, "making the fear-filled fifties but a precursor to the radical sixties" (52). The New Left of the 1960s, in sum, did not emerge out of thin air. An assemblage of radical pacifists, anti-Stalinist socialists, refugees from the Communist Party, bohemian beats, and community organizers, encouraged by rising civil rights sentiment, were ready to open a new season. In the following pages, Brick and Phelps reconstruct the rise of the Movement by focusing mainly on the two "signature organizations of the new radicalism," notably the Students for a Democratic Society 
(SDS) and the Student Nonviolent Coordinating Committee (SNCC), and explain how cultural marginality was embraced by numbers "no longer quite so marginal" (117). Certainly, the authors provide little new information about this period, especially because literature on US radicalism has been incessantly growing in recent years, ${ }^{4}$ yet they are able to arrange the facts in a compelling way and to encapsulate their historical meaning with elegance.

According to Brick and Phelps, the late 1960s and early 1970s saw what was "the deepest and broadest radicalization of the twentieth century in the United States," (124) and 1968 represented, like in France and in many other Western countries, the revolutionary year par excellence. By 1970, the leftist rebellion "was cresting with tremendous scope and force." Mao's Cultural Revolution drew the crowds, and the Third World revolutionaries were eulogized. The SDS moved from protest to resistance, while the Weathermen and a few other minor fringe groups started testing "new extremities in radical marginality" by street-fighting and bombing properties (156). Meanwhile, the black liberation movement escalated violence and offered a model of contention for white leftists. However, the American radical left, within a couple of years, fell prey to factionalism and experienced a great fragmentation while it was suffering harsh repression.

At this point, Brick and Phelps' account intersects the subject of this review: the ideological craze underwent internal criticisms and was doomed to isolation. The book seems to suggest that the background of American radicalism-always in dialectical tension between margin and mainstream, and irrigated by a multifaceted culture - provided antibodies against dogmatism and extremist excesses. For example, renowned conscientious objector Staughton Lynd, "in his search for a middle way between absolutist pacifism and unrestrained revolutionary violence," argued against torture by any party and criticized the International War Crimes Tribunal for investigating only US and South Vietnamese government atrocities, not the ones committed by Communists (141). Similarly, the authors recall that the Weathermen received expressions of disapproval and blame from their own potential allies and constituencies within the movement (e.g., the antiwar Moratorium committee). Therefore, "hypermilitancy" was generally labeled as "strategically unwise" and insulated (161).

Leaving aside a few exceptions, American radicals not only avoided violent escalation, but also prevented a backlash against political engagement. As the research demonstrates, militants "continued to remain active and look forward, inspired by hope of contributing to the germination of a new society" (176). They were able to orient themselves for the long duration. Brick and Phelps go as far as to write that, for many, "1968 was but a dress rehearsal for a more effective social revolution," and there was "a sense that opposition to 'the system' was in many ways more plausible than ever in the 1970s" (177). To be sure, radicalism was less frequently found on the news and the privatization of the "me decade" was tangible, but the 1970s were 
marked by the return to "more serious forms of below-the-radar organizing" (181).

The book, indeed, provides a wide array of evidence supporting this argument. For example, the women's and gay liberation movements, with their longterm engagement and enduring effects on American life, clearly demonstrated that revolution was not a one-time event. Furthermore, significant numbers of radicals turned themselves toward the working class, while others focused on community organizing. Trotskyist organizations experienced "growth, energy, and hardening." The so-called New Communist Movement, of Maoist descent, was able to develop and strengthen; it kept alive, at least for a while, Third World Marxism, antiracism, and proletarian orientation, yet criticized "armed struggle" fantasies (193). Finally, the new mass environmentalist movements had a strong radical component that often succeeded "in surmounting the breach between the more countercultural radicals and mainstream locals in a bridge between margin and mainstream" (206).

As Brick and Phelps clarify, left-wing fortunes seemed to deteriorate rapidly as the decade turned. However, during the age of Reagan, American radicalism demonstrated resiliency, continued to innovate, and even won some important battles. Noam Chomsky's 1988 statement-"This country is more dissident now than at any time I can remember" - was certainly hyperbolic, yet some of the largest social mobilizations in American history actually occurred during the course of the 1980s. As a matter of fact, on June 12, 1982, one million people marched through the streets of Manhattan for a huge rally in favor of a Nuclear Freeze, giving rise to the most massive peace action in American history. More generally, as the authors summarize,

[f]eminists, gays and lesbians, civil libertarians, and religious progressives contested the evangelical right's agenda. Labor activists and farmers pushed back against economic retrenchment. Radical ecology spawned new tactics and philosophies. Themes of solidarity and survival were voiced by those opposed to the nuclear arms race, U.S. intervention in Central America, and South African apartheid (221-22).

The 1980s, at odds with the 1960s, clearly saw a rapprochement of radicalism with liberalism and a critical reconsideration of Marxist ideologies. Yet, such changes just confirmed the pragmatism of American radicalism, its capacity to adapt, and its ability to think strategically for the long run.

Ultimately, that David Horowitz and Peter Collier, onetime editors of leftist magazine Ramparts, turned conservative in the 1980s, or that Black Panthers founder Bobby Seale published a book on barbeque, or, again, that Jerry Rubin became a Wall Street regular, are definitely worth remembering, but those facts do not have any paradigmatic value. As Radicals in America suggests, US radicalism well survived the ideological bottlenecks of 1968, thanks to its history and multifaceted cultural backdrop. 
Contrary to the American case, the Japanese radical left seems to have been, at least since the early 1970s, always and exclusively at the margins. Why is "the New Left of the 1960s" still considered the last significant rebellious generation in Japan's postwar history? Why does the legacy of the New Left seem to have today completely vanished? The third book under review, Japan's New Left Movements: Legacies for Civil Society by historian Takemasa Ando, seeks to answer such questions with one of the first comprehensive historical reconstructions of Japanese leftist radicalism, from the 1960s until the post-Fukushima protests of 2011. Quite naturally, Ando's attention turns to the ideological infatuation of 1968 and its controversial outcomes. The research draws on a wide array of documentary primary sources-mainly the movement's printed materials - and provides an analytic narrative that stands out in its clarity. Although social movement scholars could find it fairly weak in methods and historians could question a certain abuse of anecdotal evidence, the book has the great merit of opening the Pandora's box of the Japanese radical left for the English-speaking academic community. ${ }^{5}$ Before Ando, only Tom Havens, Patricia Steinhoff, and a few others offered substantial contributions to the subject, but they mostly focused on the Japanese antiwar movement and the leftist armed fringes. ${ }^{6}$

Ando adopts a far-reaching definition of the "New Left" that in the 1960s and 1970s included a broad range of constituencies, from anti-Vietnam War protesters to young workers. The book repeatedly insists on two peculiar features of Japanese radicalism. The first is a critique of the so-called "everydayness" - that is, the depoliticization, apathy, and conformism of people's lives within the affluent and disciplined society. The concept, which one would immediately attribute to Marcuse or Habermas, according to Ando had autochthonous roots, being employed in Japan since the 1920-1930s, notably by intellectual Tosaka Jun. ${ }^{7}$ The second is the focus on individuals' "self-revolution" as an indispensable first step for defeating everydayness and addressing larger political and social issues.

Interestingly, Ando explains the radicalization of the late 1960 s as a result of the frustration experienced by radical militants in their attempts to renovate themselves and the country at large. As Ando puts it, they felt a "lack of benchmark" to measure to what extent they had achieved such transformations. Therefore, direct action and violence against police-always presented as counter-violence - helped them find "a sense of living" and a feeling of accomplishment (74-75). A small number of militants formed guerrilla armed groups and undertook a full-fledged process of militarization, whereas the majority of them rapidly demobilized by 1970 . The book disregards the fate of the guerrillas and their, in some ways, spectacular actions. Instead, it lingers on the factors that brought the average militant to abandon ideological fascination and engagement in radical politics.

Overall, two main factors were key. On the one hand, policing was firm and particularly harsh, but also strategically advanced. Around 1970, after massive arrests and even bloody confrontations in the early stages $-1,600$ students 
were arrested during the struggles at the University of Tokyo and many were expelled or dropped out voluntarily because of the trauma (104)-police reviewed their approach to controlling contentious movements. The new strategy, in order to grasp people's demands and to cooperate with them for gathering information, aimed to build closer connections with citizens. Therefore, Japanese police were able to, first, deter protesters and, later, to avoid public opinion turning against them. Moreover, police and complicit media also succeeded in disseminating the image of young leftists as brutal and selfish extremists. Isolation of radical activists grew further when some residents, who were concerned about damage from confrontational actions, organized vigilante groups to defend themselves. Remarkably, by 1969, about forty "private selfprotection groups" against the leftist excesses were established in several districts of Tokyo. By the end of the decade, radicals had definitely lost any public support (85-86).

On the other hand, leftists' focus on the self-transformation of lives led to internal tensions. Irritation at the lack of change in individual habits spawned personal attacks and inner feuds. The practice of self-criticism, widely diffused also in Japan, did not help in overcoming errors and limits, but mostly exacerbated conflicts. The gruesome purges of the United Red Army in the winter of 1971-1972, when twelve militants killed each other in a mountain lodge amid accusations of revolutionary defeatism, shocked an entire generation and, of course, contributed to further tarnishing the public image of leftists.

Ashamed and isolated, Japanese radicals of the early 1970s realized that the gap between personal transformation and social change was too wide. So, they completely lost any expectation of political revolution based on ideological commandments. As the book reads, "the idea of transforming the 'everydayness' eventually became more a question of ethics" (97). Thus, in the most appealing part of the book, Ando explains how some leftists "sought to find a way of making their commitment sustainable" and began to organize the so-called "alternative learning movement" (110). This experience-a return to humbleness, so to speak - represented a combination of both learning from people and activism against injustice. This renovated movement, on one hand, proposed reorienting to the daily lives and to the local, through fieldwork and community-based engagement; on the other hand, it envisaged cross-border campaigns. For instance, many alternative learning activists took part in initiatives to protect rural areas endangered by industrial development, infrastructure building, and depopulation. Many others protested against pollution export from Japan to other Asian countries, as well as other alleged Japanese "colonial" habits. For example, the Asian Women's Group, a Japanese Women's liberation group established in 1977, exposed the violence and oppression that women still suffered in Asian countries and fought to denounce legal prostitution in South Korea, largely alimented by Japanese tourism.

Nonetheless, according to Ando's research, this stream of activism had little or no impact on subsequent Japanese politics. The book touches upon a few explanations for this failure, but they seem quite elusive; existing 
progressive parties were detached from the leftist milieu, European-style green parties did not emerge, antinuclear protests were dominated by the Old Left, and the new movements of the 1970s failed to build solid networks. As a result, the legacy of the New Left "for civil society," as the subtitle runs, today looks faint, not to say undetectable. The massive rallies that followed the 2011 Fukushima nuclear disaster and the ensuing political crisis bear no sign of the 1960s' radical ideas and repertoires. The new activist culture, "alive" and "joyful," based on volunteering rather than revolutionary dogmas, seems to come from nowhere.

If the Japanese youth had been only tangentially attracted by the leftist revolutionary dreams of the 1960s, its coeval Chinese Red Guard generation, on the contrary, was fully embedded in radicalism. As widely acknowledged, the young defenders of the Maoist credo inflamed China between 1966 and 1969 and became an archetype of revolutionary zeal-even fanaticism-across the world. Predictably, their story has received a great deal of attention in historiography, memoirs, and fiction. ${ }^{8}$ However, Guobin Yang's The Red Guard Generation and Political Activism in China succeeds in bringing a new perspective to the understanding of Red Guard radicalism by tracing a long-term "biography" of such a militant cohort. Instead of focusing exclusively on the few years of furor, the author opts for an original account of the gradual transformation of this political culture, covering almost five decades, from the mid-1960s until the present. Therefore, Yang investigates how the hallowed revolutionary tradition undertook a process of "desacralization" and Maoist idolatry was silently rejected in favor of "a new sense of self and society" that nurtured the following political cycles during the 1970 s and 1980s. The author finally attempts to make sense of the selective, factionalized, and shifting memories of the Red Guard generation in contemporary China. A professor of communication and sociology at the University of Pennsylvania, Yang delivers not only an accessible book, written with punch and clarity, but also a thoroughly researched historical account.

Persuasively, Yang questions the exceptionalism of China's history and frames the Red Guards "as part of a global 1960s generation." A generation, he writes, that almost everywhere "found itself in the middle of radical social movements" (7). The context of a Communist authoritarian regime, with a semidivine leader that manipulated young students against its own party's bureaucracy and internal rivals, seems worlds away from the democratic nations where the above-described leftist youths were raised. Moreover, the Red Guards lacked many of the social and educational characteristics that radical leftists generally shared. Nonetheless, the author's focus on both the revolutionary craze of young people born around 1949 and their critical revision of it allows the reader to lean the Chinese case against those of other countries.

The first part of the volume seeks to explain the logic and the genealogy of the Red Guard movement's "factional violence." With this aim in mind, the author takes into consideration the exemplary case of Chongqing, a large municipality that witnessed some of the most violent fights in the country, and 
surveys the political culture that nurtured the revolution. As Yang explains, this peculiar student protest did not question the legitimacy of the regime in power, but, quite paradoxically, stemmed from both loyalty to Mao and revolutionary orthodoxy. Students autonomously started questioning teachers, party functionaries, and work team leaders for their lack of rigor. One of the Red Guards' major polemics, for instance, centered on the privileges of family origin implicit in the policies of the Chinese Communist Party. In other words, the regime had created a caste system that manifestly contradicted basic revolutionary axioms. If municipal authorities treated young rebels as counterrevolutionaries and opposed them, central elites, including Mao and the Cultural Revolution Small Group, praised them as heroes and supported their efforts.

Both factions, caught in revolutionary competition, eventually organized like military units, giving rise to armed battles in schools, streets, and factories. The conflict was so intense that the use of rifles and heavy artillery became rather common. "To the Red Guard generation," - states Yang - "no revolution would be a true revolution without violence" (43). The spiraling cycle of violence ravaged the area of Chongqing for more than a year, until it was stopped by the deux ex machina-Mao himself. Like in the rest of the country, a newly established Municipal Revolutionary Committee absorbed members of both factions and placated the conflict.

In the subsequent section, the author explains that the entire education of the Red Guard generation - ten to thirty million people, considering the 1965 student population (6) - in the seventeen years between the foundation of the Popular Republic and the Cultural Revolution was suffused with messages of heroic martyrdom. Revolution became a holy word, while war heroes were idealized and proposed for emulation. Monuments, museums, memorials, parades, paintings, movies, music, and even children's books apotheosized utopianism and cheered political zeal. The Quotations of Chairman Mao, as everyone knows, were memorized by millions. In addition, the propaganda subtly fed domestic fears and inflated external threats. Sometimes Yang yields to the temptation of describing young Chinese as totally brainwashed and fully indoctrinated, offering a portrayal that lacks the nuances an historian would expect. Yet, the author is convincing when he shows that a generation bred in such a context was likely to express dissent in the true believers' form.

Surprisingly, "at the very moment when it imagined itself to be making a revolution," the Red Guard generation "was undoing its own revolutionary convictions" (90). As The Red Guard Generation and Political Activism in China compellingly demonstrates, the so-called "sent-down" national campaign was key in this process of reconsideration. Between 1967 and 1969-after Mao realized that the Red Guards had gotten out of control-about 4.6 million students, whose majority consisted of Red Guards, were sent from their urban residences to settle in China's vast rural areas for being farmers. Other sent-down campaigns were launched in the following years, until about 1980 when, on the whole, seventeen million students had been sent to the countryside. The official objective, in line with the Maoist canon, was to provide revolutionary students 
with "reeducation among the poor, lower, and middle peasants" (100). However, by the end of the sent-down movement, the young participants had experienced a deep personal transformation, attained a new understanding of the values of ordinary life, and began to see the emptiness of the Maoist rhetoric. Such conversion, underscores Yang, "provided the social foundation for China's great reversal from the ideology of class struggle to the ideology of economic development" (95).

Drawing on personal memoirs, private correspondence, and underground publications, the book sheds light on the cultural shock that young students experienced when they first settled in villages. In that context, political rhetoric and the reality of rural China immediately collided and appeared irreconcilable. For example, Maoist core values had always praised collective and revolutionary goals while condemning individualism as criminal. "Down with the self" was indeed one of the most frequently repeated slogans. Yet, in the countryside, people were naturally egoistic and down-to-earth. "Farming for yourself" seemed to be the rule, and no one, apparently, would sacrifice personal interests for the sake of the collectivity. Another example concerns sex. Urban Maoist culture generally repressed sexuality; even simple talk about sex had been considered shameful and immoral. Among villagers, however, former Red Guards found that sex was a perpetually fascinating topic of discussion as well as a quite unabashed habit. As a consequence, revolutionary self-denial and asceticism grew increasingly odd. Overall, as the book puts it quite emphatically, Chinese students rediscovered a notion of the people as "ordinary individuals with personal likes and dislikes, thoughts and feelings," capable of choosing their own directions for progress (112).

During the sent-down period, this erosion of political idealism developed not only throughout the interaction with ordinary rural people, but also by means of an underground cultural movement that Yang aptly describes. In contrast to the high political culture enforced by the Maoist élite, this subversive juvenile culture desacralized revolutionary values through miscellaneous forms of semiopen or clandestine activities. These included the writing of letters, diaries, poems, songs, essays, and novels, together with the large-scale circulation of "forbidden books," ranging from pamphlets on political dissent to foreign fiction. Such reappropriation of cultural instruments diffused among the former Red Guards a new sense of "transgression" and "self-cultivation" (120-21).

Remarkably, the author emphasizes that, despite psychological traumas and disillusionment, hope for a better society lived on within the Red Guard generation. The above-described shift in the way young students imagined the world was a crucial step in the history of contemporary China. Triggering "a farewell to idolatry" (4), this critical turn not only dissolved the Red Guard movement, but also enabled the subsequent wave of protest from 1976 to 1980 and, indirectly, paved the way to the 1989 student uprising. To buttress his argument, in the last section of the book Yang focuses on the often disregarded April Fifth Movement of 1976, namely the most powerful explosion of 
popular unrest since the end of the Red Guard movement and the first outburst of a new cycle of contention against the regime. The volume also stresses the importance of the so-called Democracy Wall movement, the sent-down youth protests of 1978-1979, and, finally, the agitation during the democratic electoral campaigns in 1980. This 1976-1980 wave of protest made both the residual cult of Mao and the legacy of the Cultural Revolution its main targets. While adopting nonviolent repertoires of action, the former Red Guards advocated ideas such as "enlightenment," "democracy," "rule of law," "human rights," and "political reform." This radical reversal-Yang consistently claims - "was the unintended consequence of the Red Guard movement" (159) and inaugurated a new era of enlightenment.

The book then closes with a less intriguing section that aims to explain why the memory of Maoism and the Cultural Revolution keeps on haunting Chinese society and politics. In a nutshell, Yang's explanation is as simple as it is tautological: contemporary memories are "factionalized" because of factional conflicts of the past. Even less convincing are the author's final remarks expressed in the form of paternalistic advices, such as the distrust for everything societies hold sacred. Nonetheless, The Red Guard Generation and Political Activism in China is for the most part a beautifully written and finely argued work. Unpacking the logic of the Red Guards' ideological craze and violence, Yang's volume made the Chinese history of the 1960s and 1970s less exotic and more comparable with the Western cases, while simultaneously engaging both historical and sociological readerships.

In conclusion, the four books under review underscore the idea that coming to terms with ideological infatuation was an articulated process, surely painful, but also, under certain conditions, productive of new political awareness. The 1970s and the 1980s represented an epoch of continuous activism in a form that does not coincide with the alleged depoliticization. While gradually repudiating utopian extremism, a portion of this rebel generation-coming to maturity-kept hope and radicalism intact. Far from abjuring their beliefs, most of them reconfigured politics by channeling idealism into new forms of engagement. Accounting for the peculiar historical and cultural contexts, the four case studies illuminate the logic of leftist deradicalization by suggesting at least four recurring patterns.

First, the ideological and behavioral shift always coincided with a displacement, either toward the local-getting closer to "the people"-or across national borders. The urban student background that this rebellious generation had in common led to isolation from real life, excessive intellectualization of problems, and ideological conformism. Learning from rustic villagers, revolving around community-based engagement, or engaging in transnational human rights activism were similar ways to win over such encapsulation. Interestingly, after the ideological furor evaporated, ethical concerns and moral imperatives emerged quite regularly, as if activists sought a return to the origins of their engagement. Second, radicalization was largely a matter of ideas. Symmetrically, deradicalization largely benefited from the circulation 
and contamination of ideas. The leftists' connection with broader cultural debates in France and in the United States, as well as the dissemination of underground writings and foreign books in China, showcased the extent to which the cross-pollination of ideas laid bare ideological excesses. Third, the legacies of the past were crucial. The palingenetic spirit of the 1960s should not mislead the observer. The past was key for radicalizing young leftists and later became a resource to critically engage with their own political militancy. This was particularly the case in France, where the memory of antifascism and resistance generated important afterthoughts, but was also relevant in the USA where a tradition of nonviolent and pragmatic radicalism contributed to restrain violent temptations. Fourth, the practice of self-criticism within groups of Maoist ascent fostered a dialectic method of revision, leading to constant amendment of opinions and adjustment of behaviors. Paradoxically, Maoism itself provided the tools to deconstruct the infatuation with revolution and, finally, to uncover the tension between reality and illusion.

\section{NOTES}

1. See, for instance, Tore Bjørgo and John Horgan, eds., Leaving Terrorism Behind: Individual and Collective Disengagement (London/New York, 2009); Daniel Koehler, Understanding Deradicalization: Methods, Tools and Programs for Countering Violent Extremism (London/New York, 2017).

2. Samuel Moyn, The Last Utopia: Human Rights in History (Cambridge/London, 2010), 5.

3. Cf. Julian Bourg, From Revolution to Ethics: May 1968 and Contemporary French Thought (Montreal/Kingston, 2007). See also, among the others, Michael S. Christofferson, French Intellectuals against the Left: The Anti totalitarian Moment of the 1970s (New York/ Oxford, 2004). Furthermore, Isabelle Sommier sharply analyzed the demise of violence within the French left and brought to light a panoply of cultural and sociological variables to explain it; cf. Isabelle Sommier, La violence politique et son deuil : l'après 68 en France et en Italie (Rennes, 1998).

4. See, for example, Arthur M. Eckstein, Bad Moon Rising: How the Weather Underground Beat the FBI and Lost the Revolution (New Haven, 2016); Richard Flacks and Nelson Lichtenstein, eds., Port Huron Statement: Sources and Legacies of the New Left's Founding Manifesto (Philadelphia, 2015).

5. For example, the recent William Andrews, Dissenting Japan: A History of Japanese Radicalism and Counterculture from 1945 to Fukushima (London, 2016) draws extensively on Ando's research.

6. Cf. Thomas R. H. Havens, Fire Across the Sea: The Vietnam War and Japan, 1965-1975 (Princeton, 1987); Patricia G. Steinhoff, "Hijackers, Bombers, and Bank Robbers: Managerial Style in the Japanese Red Army," Journal of Asian Studies 4 (1989): 724-40; Patricia G. Steinhoff, "Transnational Ties of the Japanese Armed Left: Shared Revolutionary Ideas and Direct Personal Contacts," in Revolutionary Violence and the New Left: Transnational Perspectives, eds., Alberto M. Álvarez and Eduardo R. Tristán (New York/London, 2016), 163-81.

7. Cf. Herbert Marcuse, One-Dimensional Man: Studies in the Ideology of Advanced Industrial Society (Boston, 1964); Jürgen Habermas, Legitimation Crisis (Boston, 1975).

8. See, among the most recent scholarly publications, Michel Bonnin, The Lost Generation: The Rustication of China's Educated Youth (1968-1980) (Hong Kong, 2013); Yarong Jiang and David Ashley, Mao's Children in the New China: Voices from the Red Guard Generation (New York, 2000); Daniel Leese, Mao Cult: Rhetoric and Ritual in China's Cultural Revolution (Cambridge, 2011). 